\title{
Infrastructure Bonds as a Funding Tool for Attracting Financial Resources for Financing Railway Modernization Projects within the Framework of PPP in Ukraine
}

\author{
O.A. Yermolenko ${ }^{1 *}$, O.O. Kokovikhina ${ }^{1}$, D.I Boiko ${ }^{1}$, N.M. Lysonkova ${ }^{1}$ \\ ${ }^{1}$ Ukrainian State University of Railway Transport, Kharkiv, Ukraine \\ *Corresponding author E-mail: yermolenko@kart.edu.ua
}

\begin{abstract}
The article concerns the analysis of the funding sources for modernization projects at OJSC Ukrzaliznytsia (UZ). Moreover, it has been proved that the self-financing enterprises of UZ in the process of expanded creation are inefficient. It is noted that infrastructure bonds within the framework of public-private partnership (PPP) may become a new promising form of financing infrastructure projects in Ukraine. The analysis of the international practice made it possible to identify some of the features functioning infrastructure bonds and its specifics for the railway industry. It has been established that advantages of this type of securities cause increased interest to them from the stock market participants, both nonprofessional and portfolio investors, which include insurance companies, investment funds and pension funds. It is proposed to the issuance of infrastructure bonds with the rate of return "average deposits rate of Ukrainian banks plus 3\%". Such a rate of return in the conditions of existence of state guarantees would interest to potential investors. The purpose of the article is to reveal the content and features of the use of infrastructure bonds in financing public-private partnership projects in the railway industry and to substantiate the practical recommendations for their application.
\end{abstract}

Keywords: institutional investor; infrastructure bonds; project funding; Public-Private Partnership (PPP); railway.

\section{Introduction}

European integration remains one of the main priorities of the state policy of the Ukrainian government. However, the national transport network, including railway industry, still fails to meet the standards, norms and requirements of the European Union and Council of Europe. There is a significant delay in the legislative, regulatory and technical basis, infrastructure and quality of the traction rolling stock. The property, plant and equipment of the railways are in critical condition, and the ways and methods used by the railways to stop their critical wear and tear are ineffective. The main reasons for the ineffectiveness of self-financing include high level of physical or other depreciation and expiring depreciation period the consequence of which is the railway transport requiring considerable borrowed funds. [1]. With regard to the railway infrastructure, trunk network with overdue capital repairs make up $27 \%$ of the total length, travel equipment with the lifetime above the rated one is $78 \%$ of the total, the wear of traction substations is $67 \%$ and the wear of contact network is $55 \%$.

\section{The Sources of Financing of the Modernization Projects of UZ}

The analysis shows that UZ most often uses its own funds and bank loans for modernization projects (Fig. 1).

However, using predominantly foreign bank loans for railway projects creates a risk of losing financial independence of UZ and its bankruptcy [2].
Among other sources, leasing may be used for modernization of fixed assets of UZ. UZ concluded a framework agreement with the GE Transportation for a partnership in upgrading the rolling stock traction in terms of 15 years and worth about $\$ 1$ billion. The first stage of the modernization project is the delivery of 30 diesel locomotives GE Te33a late in 2018 and in the first quarter of 2019 with a localization level of $10 \%$. GE and Ukreximbank signed an agreement worth $\$ 140$ million on the sale of traction rolling stock. The State Bank will further transfer the locomotive to the financial lease of UZ

For this purpose, in $2018 \mathrm{UZ}$ predicted attracting investment of UAH 18.7 billion, including through issuing domestic bonds for UAH 2 billion. [3].

On October 30, 2010, the Law of Public-Private Partnership came into effect, which defined the organizational and legal framework for an interaction of state and private partners and defined basic principles of public-private partnership. This law has defined new approaches of the partnership between the state, local self-government and private business in the implementation of infrastructure projects that are important for the development of the economy, ensuring the proper level of social life, improving the quality of people's life [4]. 


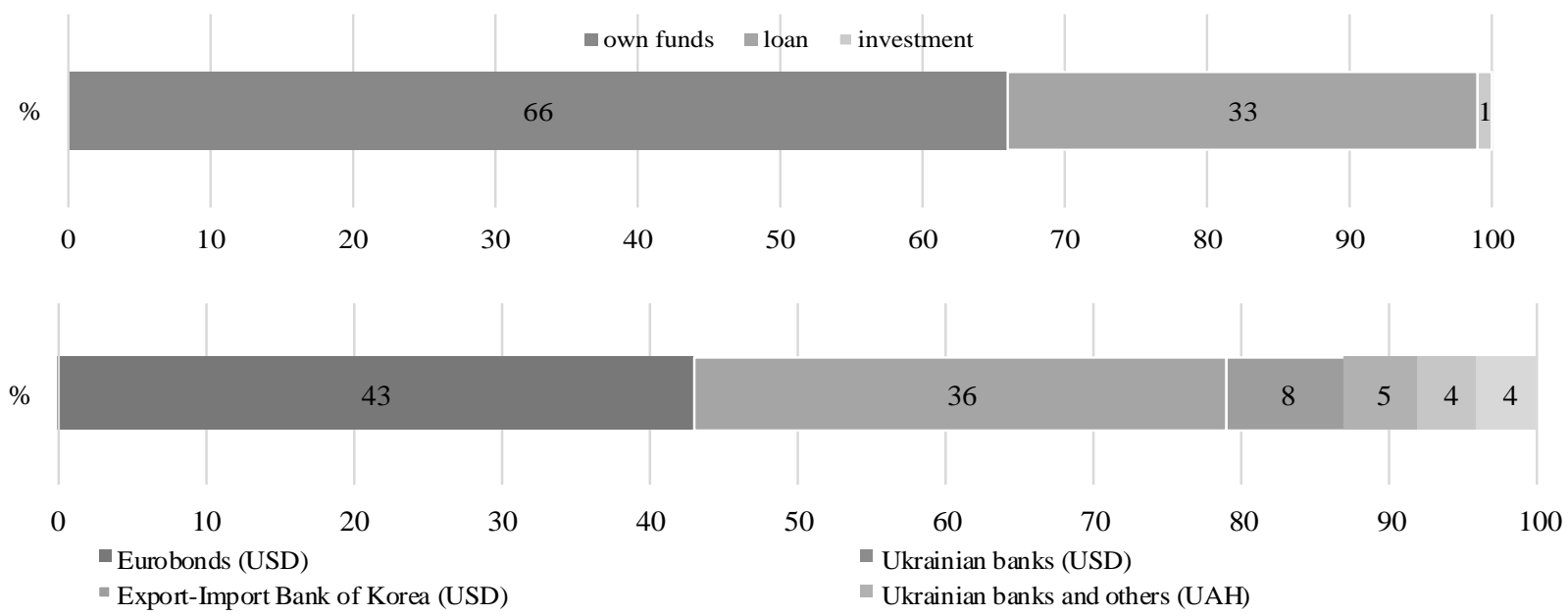

Fig. 1: The sources of financing of the modernization projects of UZ

introduces the concept of "corporate bonds" and their types:

\section{Infrastructure Bonds within the Framework of PPP in Ukraine}

Infrastructure bonds might become a new promising form of financing infrastructure projects in Ukraine. On October 10, 2013, the Verkhovna Rada adopted changes in some laws regarding the issuance of securities, which regulate the issue of infrastructure bonds for financing of infrastructure modernization within the framework of public-private partnership [5].

The development challenges of public-private partnership are discussed in the works by V. Bazylevych, E. Bondarenko, V. Varnavsky, S. Gatti, V. Grimsey, D. Delmon, M. Deryabin, T. Efimenko, I. Zapatrina, M. Lewis, Yu. Petlenko, A. Piltya, V. Rebok, Yu Sizov, Y. Tkachenko, N. Khangzhenkova, E. Cherevikova, P. Shilepnitsky and others.

\subsection{Public-Private Partnership in World Practice}

The practice of economically developed countries shows that ensuring high and sustainable rates of the country's development is impossible without the effective partnership of state authorities and private business. In foreign literature, this term is used in all forms of partnership between private business and the state. The historical origins of such partnership date back to Medieval France, where the agreement of this type was first introduced such as concession agreement [6].In the world practice, publicprivate partnership is interpreted in such aspects as:

- system of relations between the state and business, which is widely used as an instrument of economic and social development at the international, national, regional, local levels;

- $\quad$ specific projects implemented jointly by state authorities and private companies on the basis of objects of state and municipal property [7, p. 12].

The public-private partnership is a universal system for achieving a number of long-term targets. The purpose of the partnership is total benefit from pooling the public and private sectors. The participation of the private business in the implementation of socially significant innovation and investment projects will become active and effective only if the state provides a balance of risks and benefits.

On August 1, 2012, the National Commission on Securities and Stock Market of Ukraine published a draft law "On Amendments to the Law of Ukraine" On Securities and the Stock Market "regarding the development of the bond market." This document infrastructure, stock exchange, concession. On November 10, 2013, this draft was adopted by the Verkhovna Rada of Ukraine in the first reading as the basis of the law "On Amending Certain Legislative Acts of Ukraine regarding Issuance of Securities" [8]. Under this law, infrastructure bonds are corporate bonds placed by the enterprise with the purpose of attracting funds intended to finance the creation and/or restoration (reconstruction, modernization) of infrastructure carried out in accordance with an agreement included into the framework of the public-private partnership.

Infrastructures bonds are bonds issued for attracting financing of infrastructure objects. Typically, infrastructures bonds have a maturity of at least 5 years with turnover times near 15-20 years, i.e. their terms are comparable with terms of retirement obligations.

The attractiveness of infrastructures bonds in comparison with other instruments is caused by tax privileges and state guarantees provided both on the principal amount of the debt on bonds and in relation to the corresponding income received by investors for the provision of funds for the implementation of the project. The experience of other countries proves that the advantages of such documents attract increased interest on the side of stock market participants.

Infrastructure bonds are widely used in many countries, such as the USA, Australia, Chile, India, etc. [9].

Issuing infrastructure bonds meets the demand in investment resources for the state and private business, as well as offers new kind of long-term, guaranteed paper for a market.

\subsection{Features of the Use of Infrastructure Bonds in Financing Public-Private Partnership Projects in the Railway Industry}

The analysis of the international practice of using infrastructure bonds functioning within the framework of PPP and the specifics of the railways allows us to identify the features inherent to infrastructure bonds. [9-13].

1 The issuance of infrastructure bonds is carried out with the support of the state. The state is interested in projects that have a social orientation or will contribute to European integration. For infrastructure bonds, state support may take the form of direct or indirect guarantees. Foreign countries take all possible measures to encourage the development of bond financing and take all possible measures, including:

- granting tax privileges for bondholders in the form of privileges for the corporate income tax and profit tax of individuals; 
- granting tax concessions to the concessionaire's, such as land tax benefits, etc.;

- granting state guarantees for the concessionaire's monetary obligations to the infrastructure bondholders;

- bonds bail as a loan collateral provided by a state bank in order to attract credit institutions as investors.

Legislation of foreign states is also known for the support of infrastructure bonds by local authorities. This may be in the provision of municipal guarantees or additional tax privileges, taking into account the territory of the implementation of the infrastructure project [9].

2. The issuer of infrastructure bonds, in this case, maybe a joint venture, specially created for the implementation of a specific investment project.

3. The earmarked issuance of infrastructure bonds.

In this way, with the help of such bonds, was completed the construction of the pipeline in Qatar ( $\$ 800$ million for a term of 18 years) and the construction of the railway in Hong Kong (\$1000 million for a term of 10 years) [10].

One of the newly launched investment projects, where issue of project bonds is planned, is the construction of solar power plants in California, the USA. In December 2010, SunPower Corporation has issued project bonds worth 195.2 million euros. This issue consists of project bonds of two series: A1 with interest rate $5.715 \%$ per annum and A2 with interest rate 4.839 per annum. The repayment is scheduled to 2028 [14]

4. Infrastructure bonds are less risky in comparison with ordinary bonds. For any emitter issuing infrastructure bonds will able to pay profit by bonds only in a situation when the project will be profitable, and how much real cash flows will match with planned cash flows. Obviously, the main purpose of investment activity of any enterprise is to increase the profit from investment activities with a minimum level of risk investment. Investment risk is the likelihood of a loss in the form of a reduction of capital or loss of profit due to the uncertainty of the terms of investment activity. In practice two main types of risks are singled out: general (systematic) risks - the same for all participants in investment activity and which are determined by factors that the investor cannot influence; specific risks - risks that depend on the ability of the investor to choose the objects of investment with acceptable risk and risk management. The main types of general risks are:

- socio-political risks,

- environmental risks,

- risks associated with measures of state regulation,

- market risks,

- inflationary risks,

- the risks poor environment for these areas of activity,

- other risks.

5. From the experience of other countries, the presence of these advantages in this type of securities causes increased interest to them from stock market participants, both nonprofessional and portfolio investors, which include insurance companies, investment funds and pension funds.

Nowadays, pension funds have four options for financing infrastructure: the purchase of shares of specialized companies, investing in infrastructure funds, direct investment, and the purchase of debt obligations. Such investments are related with standard market risks financial capacity of issuers, negative changes in market conditions, liquidity and dynamics of securities value. States that are interested in encouraging investment in institutional infrastructure invest in special funding provisions that reduce the listed risks and/or increase the return on investment. In the majority, they relate to the placement of debt securities concessional bonds or infrastructure bonds [9].

A phased scheme for the implementation loan of infrastructure bonds, respectively, may be presented as follows (fig. 2).

Identification of potential private partners who can implement an infrastructure project under the PPP and hold a project com petition

2 Concluding of the treaty on a partnership between public and private partners and concluding concession agreements

3 Preparations all documents and transfer it to National Securities and Stock Market Commission for the registration of infrast ructure bonds

4 Presentation of information on the bond issuance to potential investors

5 Issuance of infrastructure bonds in accordance with the legislation of Ukraine [13] and placement for a period of time equal to construction time and project's payback period

6 Direction of funding received from the placement of infrastructure bonds for the construction and reconstruction of an infrastructure facility

Public acceptance of an infrastructure projects

8 Collection of payments from users of the facilities (completed or reconstructed construction objects) and funding pay to the bondholders for the redemption of par value and accumulated coupon profit of bonds

Fig. 2: A phased scheme for the implementation loan of infrastructure bonds within the framework of PPP

Fig. 3 shows the proposed mechanism for attracting financial resources through the issue of infrastructure bonds within the framework of PPP. The process of implementation of infrastructure projects under the terms of a concession starts with the creation of a special legal entity, concessions award and determination of the winner. After that, the concession agreement is concluded and issuance and placement of infrastructure bonds are carried out. Purchase of infrastructure bonds is carried out by investors such as insurance companies and pension funds. After that, the attracted funds are directed to the implementation of the infrastructure project.

\subsection{The Mechanism for Attracting Financial Resources through the Issuance of Infrastructure Bonds within the Framework of PPP}

The public partner plays a leading role in promoting the use of infrastructure bonds for financing railways projects within the framework of PPP. The mechanism of attracting financial resources issuance of such bonds is based on the method of project financing (Fig. 3). 


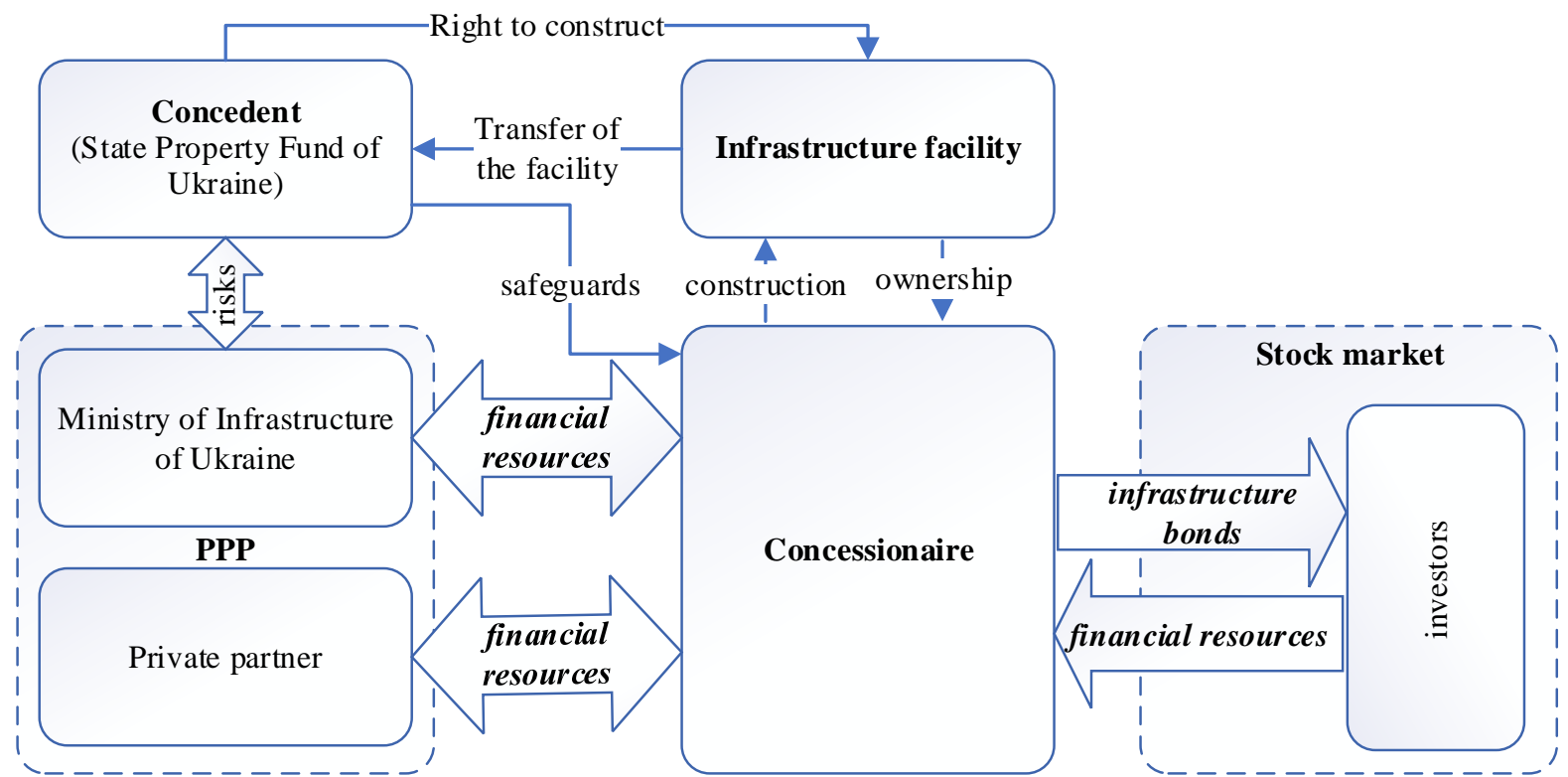

Fig. 3: The mechanism for attracting financial resources through the issuance of infrastructure bonds within the framework of $\overline{P P P}$

The Infrastructure bond is debt securities issued by the concessionaire exclusively for the financing of the construction, acquisition or reconstruction of an infrastructure object. They oblige the investor to pay the issuer the amount owed within a specified period, taking into account a certain percentage (for coupon bonds), or to make repayment bonds at nominal value (for discount bonds). To determine the profitability of infrastructure bonds is one of the important key issues in this issue. The profitability of infrastructure bonds should be comfortable for issuers and intended to provide the investment attractiveness of this means for potential investors. Lashevsky P. O. offers to consider the rate of return of infrastructure bonds as a superposition of two values. The indicator, on the basis of which one can calculate the upper limit of the profit of infrastructure bonds, is tied to the internal rate of return of the infrastructure project. As a lower profit limit, it is expedient to use the indicator "the inflation plus $1 \%$ " [16].

The use of this method in Ukraine is impossible due to the high real inflation rate. Therefore, it is expedient to base the calculation of the rate of return of infrastructure bonds by the average rates of deposits of Ukrainian banks for the corporate sector (figure.4).

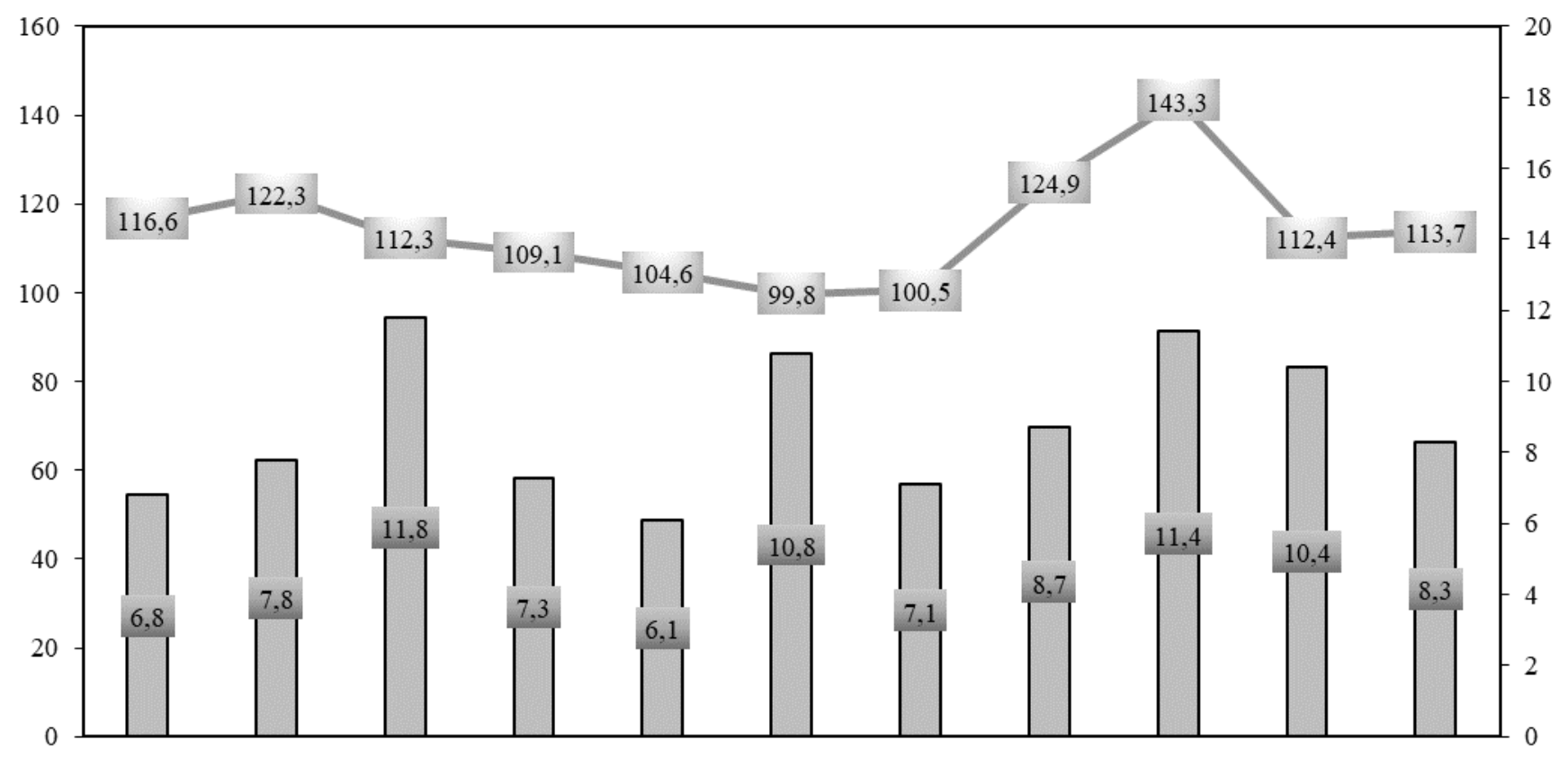

$\square$ The interest rate on Corporate Deposits (weighted average annual rates, \%)

The consumer price index (\%) (scale on the right)

Fig. 4: Dynamic of the interest rate on Corporate Deposits and the consumer price index

In our opinion, taking into account the character of the financial market and the level of inflation in Ukraine, it is expedient to the issuance of infrastructure bonds with the rate of return "average deposits rate for the corporate sector plus 3\%". Such a rate of return in the conditions of existence of state guarantees would be of particular interest to potential investors. 


\section{Conclusion}

Railway transport in Ukraine urgently needs the renovation of the old and the creation of new infrastructures objects. Infrastructure bonds that are successfully used by several states to attract capital in the transport infrastructure may be an effective instrument for solving the problem of attracting private capital to the railway infrastructure. In this case, PPP has advantages such as expanding the range of potential investors and reducing the burden on the State budget through the use of bonds.

For more efficient use of infrastructure bonds to finance PPP projects and to ensure equal opportunities for the state and business within the framework of innovation and investment projects in railway transport, the following priority measures are required:

- improving the concession legislation and regulating the mechanism of project implementation on the basis of PPP;

- Government support at all the levels of the private sector in the implementation of PPP projects;

- improvement of the legal, organizational and institutional environment for the provision of activities of participants in PPP projects based on foreign experience;

- clearly defining the procedure of interaction of participants in the issuance, placement and repayment of infrastructure bonds.

- the increase of protection guarantees of private partners' interests of PPP in the process of development, approval and implementation of projects.

The implementation of these measures will help to improve the mechanism of funding infrastructure projects of the railway transport and the appearance of new reliable instruments in the stock market to meet the needs of non-professional and portfolio investors.

\section{References}

[1] [1] Gurnak V., Savitska G., Likarenko Y. "Financial support of the railway transport fixed assets reproduction", Economics. Management. Business, No. 3(13), (2013) pp. 66-71

[2] [2] Eytutis G., Nykyforuk O., Boyko O. "Potential sources of investment in railway transport of Ukraine: opportunities for their diversification", Ukrainian Journal Ekonomist, No. 8, (2012), pp. 64-69

[3] [3] Kabmin skhvalyv vypusk oblihatsii "Ukrzaliznytsi" na 2 mlrd hrn u 2018 rotsi, [Online]. Available: http://ua.interfax.com.ua/ news/economic/485556.html

[4] [4] Zakon ukrainy pro derzhavno-pryvatne partnerstvo, Official web portal of the Verhovna Rada of Ukraine, [Online]. Available: http://zakon5.rada.gov.ua/laws/show/2404-17

[5] [5] Postanova pro pryiniattia za osnovu proektu Zakonu Ukrainy pro vnesennia zmin do deiakykh zakonodavchykh aktiv Ukrainy shchodo emisii tsinnykh paperiv, Official web portal of the Verhovna Rada of Ukraine, [Online]. Available: http://zakon.rada.gov.ua/laws/show/651-18

[6] [6] Bacho R. "Institutional aspects of the implementation of publicprivate partnership in the nonbanking financial services markets of Ukraine", Reporter of the Priazovskyi State Technical University. Section: Economic sciences, No. 33, (2017), pp. 321-332, available online: http://eir.pstu.edu/ bitstream/ handle/12345 6789 /15905/44.pdf? sequence $=1$

[7] [7] Varnavskiy V, "Gosudarstvenno-chastnoe partnerstvo v Rossii: problemy stanovlenyia" [Online]. Available: http://www.stranaoz.ru/2004/6/gosudarstvenno-chastnoe-part nerstvo-v-rossiiproblemy-stanovleniya

[8] [8] Zakon ukrainy pro vnesennia zmin do deiakykh zakonodavchykh aktiv Ukrainy shchodo emisii tsinnykh paperiv, Official web portal of the Verhovna Rada of Ukraine, [Online]. Available: http://w1.c1.rada.gov.ua/pls/

[9] zweb2 /webproc34?id=\&pf3511 $=45528 \&$ pf35401 $=248723$

[10] [9] Nykyforuk O., Chukaeva I. "Infrastructure bonds as a tool for attracting investment for needs of modernization in practice of foreign countries", Efficient economy, No. 4, (2014), available online: http://www.economy.nayka.com.ua/?op=1\&z=2926

[11] [10] Stefano Gatti, Project finance in theory and practice:

[12] designing, structuring, and financing private and public projects, Publisher: Academic Press, (2007), 414 pages

[13] [11] John D, Finnerty. Project Financing: Asset-Based Financial

[14] Engineering. Publisher: John Wiley and sons, (2011), 496 pages

[15] [12] Pierre Hillion. Project Finance [Online]. Available: http://www.slidefinder.net/1/lectureonprojectfinance/

[16] 17529198

[17] [13] Mansoor Dailami, Robert Hauswald, The Emerging Project Bond Market: Covenant Provisions and Credit Spreads. World Bank Publications, (2003), 35 pages.

[18] [14] "SunPower Closes the Industry`s First Solar Project Bonds" [Online]. Available: http://us.sunpoertcorp.com/about /newsroom/ press-releases/ ?relID $=537057$

[19] [15] Rishennia pro zatverdzhennia polozhennia pro poriadok zdiisnennia emisii oblihatsii pidpryiemstv, oblihatsii mizhnarodnykh finansovykh orhanizatsii ta yikh obihuOfficial web portal of the Verhovna Rada of Ukraine, [Online]. Available:http://zakon3.rada.gov.ua/laws/show/ z0171-14

[20] [16] Lashevsky P. "Modeling of infrastructure bond-equivalent yield", Theory and practice of social development: international scientific journal, No. 21, (2014), pp. 120-122

[21] https://elibrary.ru/item.asp?id=23049615 (in Russian) 